М.С. Быкова*

\title{
ПРОБЛЕМНЫЕ ВОПРОСЫ
}

ПРИМЕНЕНИЯ НОРМ

МЕЖДУНАРОДНОГО ПРАВА ПРИ

ОСУЩЕСТВЛЕНИИ ПРОКУРОРСКОГО

НАДЗОРА ЗА ИСПОЛНЕНИЕМ ЗАКОНОВ

О ТЕХНИЧЕСКОМ РЕГУЛИРОВАНИИ

В СФЕРЕ ОБОРОТА ПРОДУКТОВ

ДЕТСКОГО ПИТАНИЯ

Аннотация: В статье рассматриваются вопросы влияния норм международного права на национальное законодательство о техническом регулировании в срере оборота продуктов детского питания. Обосновывается необходимость включения норм международного права в предмет прокурорского надзора за исполнением законов в указанной отрасли. Исследуется значение технических регламентов, принятых в рамках Таможенного союза Российской Федерации, Республики Беларусь и Республики Казахстан по вопросам технического регулирования оборота продуктов детского питания, для правовой регламентации данной сферы общественных отношений на внутрироссийском уровне. В статье использованы общенаучный диалектический методы познания, анализ, синтез, обобщение, историческо-правовой, сравнительно-правовой, формально-юридический, системно-структурного анализа. Обращается внимание на существующее противоречие между Конституцией Российской Федерации, признающей приоритетное значение за общепризнанными нормами и принципами международного права и международными договорами Российской Федерации, и правовой природой технических регламентов, принятых решениями Комиссии Таможенного союза и Совета Евразийской экономической комиссии по вопросам технического регулирования оборота продуктов детского питания, и не являющихся международными договорами. Подчеркивается необходимость разрешения спорных вопросов, касающихся приоритета данных документов по отношению к национальному законодательству РФ, в целях определения пределов прокурорского надзора за исполнением законов на данном направлении.

Ключевые слова: Всемирная торговая организачия, международные договоры, техническое регулирование, продукты детского питания, прокурорский надзор, Таможенный союз, технические регламенты, Конституция Российской Федерации, имплементация, Конституционыый Суд РФ.

DOI: 10.7256/1994-1471.2014.6.11514

$\mathrm{H}$ аучно доказано, что питание является одним из важнейших факторов, определяющих здоровье населения, особенно детского. В глобальном смысле здоровье детей - залог здоровья будущих поколений.

Правильное питание обеспечивает нормальный рост и развитие детей, способствует профилактике заболеваний, продлению жизни людей, повышению работоспособности и со- здает условия для адекватной адаптации их к окружающей среде ${ }^{1}$.

Права и интересы ребенка в различных сферах общественной жизни всегда являлись предметом особой заботы международного сообщества.

См.: Кострова Г. И. Фактическое питание и показатели физического развития и нутритивного статуса детей. Дисс. ... канд. мед. наук. Архангельск, 2011. С. 24-25.

(C) Быкова Мария Сергеевна

* Аспирантка Академии Генеральной прокуратуры РФ

[marbyk@bk.ru]

150000, Россия, г. Ярославль, ул. Некрасова, д. 5. 
Право ребенка на нормальное развитие закреплено Конвенцией ООН о правах ребенка, Международным пактом об экономических, социальных и культурных правах.

В эпоху глобализации, взаимозависимости международное право имеет непосредственное значение в регулировании прав и защите интересов физических и юридических лиц ${ }^{2}$.

Техническое регулирование в сфере оборота продуктов детского питания в Российской Федерации, определяемое нами как государственное регулирование отношений в сбере деятельности по разработке и применению технических регламентов, стандартизации и оценке соответствия продуктов детского питания в целях обеспечения качества и безопасности для человека и окружающей среды и свободного перемещения продуктов детского питания на рынке, испытало на себе существенное воздействие норм международного права.

С момента распада СССР и образования «независимой» России одним из основных вопросов внешней политики являлось вступление России во Всемирную торговую организацию (ВТO), преобразованную из Генерального соглашения по тарифам и торговле (ГАТТ).

22.08.2012 г. Российская Федерация официально стала 156-м членом ВТ0, преодолев длительный путь выполнения необходимых условий, выдвигавшихся партнерами по переговорному процессу.

Распоряжением Правительства Российской Федерации от 08.08.2001г. № 1054-р³ был утвержден План мероприятий по приведению законодательства РФ в соответствие с нормами и правилами Всемирной торговой организации, в рамках реализации которого 27.12.2002г. был принят Федеральный закон «0 техническом регулировании» № 184-Ф34

\footnotetext{
См.: Марочкин С. Ю. Действие и реализация норм международного права в правовой системе Российской Федерации: монография. М., 2011. С. 48.

Распоряжение Правительства РФ от 08 августа 2001 г. № 1054-p «О Плане мероприятий по приведению законодательства Российской Федерации в соответствие с нормами и правилами Всемирной торговой организации» // СЗ РФ. 2001. № 34. Ст. 3511; 2002. № 26. Ст. 2613.
}

4 Федеральный закон от 27.12.2002 № 184-Ф3 «О техническом регулировании» // СЗ РФ. 2002. № 52 (ч. 1). Ст. 5140; 2005. № 19. Ст. 1752; 2007. № 19. Ст. 2293; 2007. № 49. Ст. 6070; 2008. № 30 (ч. 2). Ст. 3616; 2009. № 29. Ст. 3626; 2009. № 48. Ст. 5711; 2010. № 1. Ст. 5; 2010. № 1. Ст. 6; 2010. № 40. Ст. 4969; 2011. № 30 (ч. 1). Ст. 4603 ; 2011. № 49 (ч. 1). Ст. 7025; 2011. № 50. Ст. 7351; 2012. № 31. Ст. 4322; 2012. № 50 (ч. 5). Ст. 6959; 2013. № 27. Ст. 3477; 2013. № 30 (ч.1). Ст. 4071; 2013. № 52 (ч.1) Ст. 6961.
Данный закон испытал большое влияние норм ВТ0 5 , что являлось проявлением избранного российским законодателем способа сближения национального законодательства с нормами ВТО.

Так, в законе «О техническом регулировании» воспринята установленная в Соглашении о технических барьерах в торговле ${ }^{6}$ и Соглашении по применению санитарных и фитосанитарных мер ${ }^{7}$ классификация мер технического регулирования (обязательных технических регламентов и добровольных к исполнению стандартов), установлен принцип недопустимых препятствий предпринимательской деятельности (п. 2 ст.7, абз.5 ст.12, абз.4 ст.18), принцип национального режима (п.2 ст.15, п.2 ст.17, п.2 ст.19), принцип приоритета международных стандартов (п.8 ст.7, абз.4 п.9 ст.7, абз.4 ст.12), положение о признании иностранных документов о подтверждении соответствия (ст.30). В целом, во исполнение требований партнеров по ВТО в РФ в связи с принятием ФЗ «0 техническом регулировании», заменившим Закон РФ от 10.06.1993г. «О сертификации продукции и услуг», Закон РФ от 10.06.1993г. № 5154-1 «0 стандартизации» начала выстраиваться единая система технического регулирования ${ }^{8}$.

В последнее время роль источников международного права в регулировании общественных отношений в сфере технического регулирования в целом и, в том числе в части продуктов детского питания, особенно возрастает.

При этом одним из приоритетных направлений международного сотрудничества Российской Федерации в сфере технического регулирования в настоящее время является сотрудничество в рамках Таможенного союза (далее - ТС).

Действующими членами ТС являются Российская Федерация, Республика Беларусь и Республика Казахстан. Политика общей гармонизации законодательства и правоприме-

См.: Губарев В. И. Рецепция российским правом соглашений Всемирной торговой организации // Юрист. 2005. № 10. C. 44.

«Соглашение по техническим барьерам в торговле» (ТБТ/ТВТ) (Вместе с «Терминами и их определениями для целей...», «Экспертными группами», «Кодексом добросовестной практики применительно к разработке, утверждению и применению стандартов») // С3 РФ. 2012. № 37 (приложение, ч. VI). С. 2629-2649.

Соглашение по применению санитарных и фитосанитарных мер (CФC/SPS) (Вместе с «Определениями», «Транспарентностью правил», «Процедурами контроля, инспектирования и одобрения») // Собрание законодательства РФ. 2012. № 37 (приложение, ч. VI). С. 2566-2578.

8 См.: Губарев В. И. Указ. соч. С. 47 
нительной практики стран-участниц в целях эффективного функционирования единого экономического пространства в рамках ТС применительно к сфере технического регулирования предполагает установление единых и обязательных требований к продукции, аккредитации, проведению контроля. Вместе с тем важными факторами сдерживания развития интеграционных отношений в региональных экономических объединениях, созданных на постсоветском пространстве, специалисты считают отсутствие координации в разработке базовых соглашений по гармонизации технических регламентов государств-участников объединений и различную степень применения международных и европейских подходов в системах технического регулирования 9 .

В рамках Таможенного союза действует несколько международных договоров по вопросам технического регулирования.

К основополагающим следует отнести Соглашение об обращении продукции, подлежащей обязательной оценке (подтверждению) соответствия, на таможенной территории Таможенного союза от $11.12 .2009 \Gamma^{10}{ }^{10}$ Соглашение о взаимном признании аккредитации органов по сертификации (оценке (подтверждению) соответствия) и испытательных лабораторий (центров), выполняющих работы по оценке (подтверждению) соответствия от 11.12.2009 г. $^{11}$, Соглашение о единых принципах и правилах технического регулирования в Республике Беларусь, Республике Казахстан и Российской Федерации от 18.11.2010г. ${ }^{12}$, Соглашение об основах гармонизации технических регламентов государств-членов Евразийского экономического сообщества от 24.03.2005г. ${ }^{13}$, Соглашение о проведении согласованной политики в области техниче-

См.: Морозов А. Н. Международно-правовые аспекты технического регулирования в Таможенном союзе // Журнал российского права. 2012. № 4. С. 78.

10 Соглашение об обращении продукции, подлежащей обязательной оценке (подтверждению) соответствия, на таможенной территории Таможенного союза // СЗ РФ. 2010. № 40. Ст. 4985.

11 Соглашение о взаимном признании аккредитации органов по сертификации (оценке (подтверждению) соответствия) и испытательных лабораторий (центров), выполняющих работы по оценке (подтверждению) соответствия // СЗ РФ. 2010. № 40. Ст. 4986.

Соглашение о единых принципах и правилах технического регулирования в Республике Беларусь, Республике Казахстан и Российской Федерации // СЗ РФ. 2012. № 5. Ст. 536.

13 Соглашение об основах гармонизации технических регламентов государств - членов Евразийского экономического сообщества // Бюллетень международных договоров. 2008. №8. С. 23-26. ского регулирования, санитарных и фитосанитарных мер от 25.01.2008г. ${ }^{14}$

Пищевая продукция включена в Единый перечень продукции, в отношении которой устанавливаются обязательные требования в рамках Таможенного союза, утвержденный решением Комиссии Таможенного союза от 28.01.2011г. № 526.

09.12.2011г. Комиссией Таможенного союза, выполнявшей до конца 2011 года функции исполнительного органа Союза, приняты Технические регламенты Таможенного союза: «0 безопасности зерна» ${ }^{15}$, «0 безопасности пищевой продукции» ${ }^{16}$, «Пищевая продукция в части ее маркировки» ${ }^{17}$, «Технический регламент на соковую продукцию из фруктов и овощей» ${ }^{18}$, «Технический регламент на масложировую продукцию» ${ }^{19}$.

14 Соглашение о проведении согласованной политики в области технического регулирования, санитарных и фитосанитарных мер // Бюллетень международных договоров. 2012. № 8. С. 48-49.

Решение Комиссии Таможенного союза от 09.12.2011 № 874 «О принятии технического регламента Таможенного союза «О безопасности зерна» (вместе c «ТP ТС 015/2011. Технический регламент Таможенного союза. «О безопасности зерна») // Официальный сайт Комиссии Таможенного союза http://www.tsouz. ru. 15.12.2011.

16 Решение Комиссии Таможенного союза от 09.12.2011 № 880 «О принятии технического регламента Таможенного союза «О безопасности пищевой продукции» (вместе с «ТР ТС 021/2011. Технический регламент Таможенного союза. О безопасности пищевой продукции») // Официальный сайт Комиссии Таможенного союза http://www.tsouz.ru. 15.12.2011; официальный сайт Евразийской экономической комиссии http://www. eurasiancommission.org. 02.07.2013.

Решение Комиссии Таможенного союза от 09.12.2011 № 881 «О принятии технического регламента Таможенного союза «Пищевая продукция в части ее маркировки» (вместе с «ТР ТС 022/2011. Технический регламент Таможенного союза. Пищевая продукция в части ее маркировки») // Официальный сайт Комиссии Таможенного союза http://www.tsouz.ru. 15.12.2011.

18 Решение Комиссии Таможенного союза от 09.12.2011 № 882 «О принятии технического регламента Таможенного союза «Технический регламент на соковую продукцию из фруктов и овощей» (вместе с «ТР ТС 023/2011. Технический регламент Таможенного союза. Технический регламент на соковую продукцию из фруктов и овощей»)// Официальный сайт Комиссии Таможенного союза http://www.tsouz.ru.15.12.2011, официальный сайт Евразийской экономической комиссии http://www. tsouz.ru. 14.11.2012.

19 Решение Комиссии Таможенного союза от 09.12.2011 № 883 «О принятии технического регламента Таможенного союза «Технический регламент на масложировую продукцию» (вместе с «ТР ТС 024/2011. Технический регламент Таможенного союза. Технический регламент на масложировую продукцию») // Официальный сайт Комиссии Таможенного союза http://www.tsouz.ru. 15.12.2011. 
Регламенты вступили в силу с 01.07.2013г., с указанной даты прекратили свое действие как принятые на территориях стран-участников Союза технические регламенты, так и национальные стандарты, санитарные и ветеринарные нормы и правила.

До 15.02.2015 г. производителям пищевой продукции разрешается выпуск в обращение пищевой продукции в соответствии с действующими нормативными актами, установленными законодательством государств-членов Таможенного союза, при условии, что на такую продукцию до вступления в силу Технического регламента были выданы документы, подтверждающие ее соответствие установленным требованиям.

Основополагающее значение имеет Технический регламент «О безопасности пищевой продукции», устанавливающий требования безопасности ко всем видам пищевых продуктов, процессам их производства, хранения, транспортировки, реализации и утилизации, а также формы и способы оценки соответствия такой продукции. Специальные требования к отдельным видам пищевой продукции, устанавливаемые иными техническими регламентами, могут только дополнять или уточнять, но не изменять требования, установленные данным Техническим регламентом.

Технический регламент вводит несколько новых механизмов регулирования процессов обеспечения безопасности продукции.

Во-первых, в отношении юридических лиц, индивидуальных предпринимателей, осуществляющих производство пищевой продукции, вводится система их государственной регистрации. При этом государственная регистрация в отношении отдельных производств пищевой продукции животного происхождения носит разрешительный характер, предусматривающий предварительную проверку конкретного предприятия, в отношении производства иной пищевой продукции - уведомительный учетный характер.

Во-вторых, в отношении специализированной пищевой продукции, предназначенной для детского питания, питания спортсменов, беременных и кормящих женщин вводится государственная регистрация, имеющая разрешительный характер.

В-третьих, производство пищевой продукции должно осуществляться при условии обязательной разработки, внедрения и применения системы производственного контроля, основанной на принципах НАССР (разновидность международной системы добросовестной практики и управления качеством).

B-четвертых, производитель пищевой продукции обязан самостоятельно подтверждать посредством подачи декларации соответствие выпускаемой в обращение продукции требованиям Технического регламента, используя при этом по своему выбору собственные доказательства или привлекая аккредитованные испытательные организации. Вместе с тем специализированная продукция, в том числе пищевая продукция, предназначенная для детского питания, декларированию не подлежит.

И, наконец, в-пятых, отменяется ветеринарно-санитарная экспертиза с выдачей ветеринарных свидетельств на всех этапах обращения продукции животного происхождения, за исключением такой экспертизы, проводимой в отношении сырья животного происхождения ${ }^{20}$.

В конце 2011 года решением президентов Российской Федерации, Республики Беларусь и Республики Казахстан создана Евразийская экономическая комиссия (Договор о Евразийской экономической комиссии от 18.11.2011 г.21) как единый постоянно действующий регулирующий орган Таможенного союза и Единого экономического пространства (на сегодняшний день в состав входят Российская Федерация, Республика Беларусь, Республика Казахстан с возможностью присоединения других стран). Комиссия имеет статус наднационального органа управления, не подчинена какомулибо из правительств трех стран, ее решения обязательны для исполнения на территории трех стран. Основной задачей ЕЭК является обеспечение условий функционирования и развития Таможенного союза и Единого экономического пространства, а также выработка предложений по дальнейшему развитию интеграции. ЕЭК передаются полномочия упраздняемой Комиссии Таможенного союза (КТС), в том числе по техническому регулированию.

Порядок разработки и принятия Евразийской экономической комиссией технических регламентов установлен в настоящее время Положением о порядке разработки, принятия, внесения изменений и отмены технического регламента Таможенного союза, принятого Решением Совета Евразийской экономической комиссии 20.06.2012г. № $48^{22}$.

20 См.: Семенов С. В. Качество и безопасность пищевой продукции. Вопросы нормативно-правового регулирования // Торговое право. 2012. № 4. С. 32-35.

21 Договор о Евразийской экономической комиссии // С3 РФ. 2012. № 11. Ст. 1275.

22 Решение Совета Евразийской экономической комиссии от 20.06.2012 № 48 «О Положении о порядке разработки, принятия, внесения изменений и отмены технического регламента Таможенного союза» // Официальный сайт Комиссии Таможенного союза http:// www.tsouz.ru. 22.06.2012. 
В соответствии с указанным Положением правом принятия технических регламентов наделена, как раньше Комиссия Таможенного союза, Евразийская экономическая комиссия.

Решением Евразийской экономической комиссии от 15.06.2012г. № $34^{23}$ принят Технический регламент «0 безопасности отдельных видов специализированной пищевой продукции, в том числе диетического лечебного и диетического профилактического питания», одним из объектов технического регулирования которого является продукция детского питания.

Технический регламент вступил в силу с 01.07.2013г., до 1 января 2014 года допускался производство и выпуск в обращение на таможенной территории Таможенного союза продукции, не подлежавшей до дня вступления в силу Технического регламента обязательной оценке (подтверждению) соответствия согласно нормативным правовым актам Таможенного союза или законодательству государства - члена Таможенного союза, без документов об обязательной оценке (подтверждении) соответствия продукции и без маркировки национальным знаком соответствия (знаком обращения на рынке).

Решениями Совета Евразийской экономической комиссии от 9 октября 2013 года № 67 и № 68 приняты технические регламенты Таможенного союза «0 безопасности молока и молочной продукции» (ТР ТС 033/201324) и «0 безопасности мяса и мясной продукции» (ТР TC 034/2013 25 ), вступающие в силу с 1 мая 2014

23 Решение Совета Евразийской экономической комиссии от 15.06.2012 № 34 «О принятии технического регламента Таможенного союза "О безопасности отдельных видов специализированной пищевой продукции, в том числе диетического лечебного и диетического профилактического питания"» (вместе с «ТР ТС 027/2012. Технический регламент Таможенного союза. О безопасности отдельных видов специализированной пищевой продукции, в том числе диетического лечебного и диетического профилактического питания») // Официальный сайт Комиссии Таможенного союза http://www.tsouz.ru. 18.06.2012.

24 Решение Совета Евразийской экономической комиссии от 09.10.2013 № 67 «О техническом регламенте Таможенного союза "О безопасности молока и молочной продукции”» (вместе с «ТР ТС 033/2013. Технический регламент Таможенного союза. О безопасности молока и молочной продукции») // Официальный сайт Евразийской экономической комиссии http://www. eurasiancommission.org. 14.10.2013.

25 Решение Совета Евразийской экономической комиссии от 09.10.2013 № 68 «О техническом регламенте Таможенного союза "О безопасности мяса и мясной продукции” (вместе с «ТР ТС 034/2013. Технический регламент Таможенного союза. О безопасности мяса и мясной продукции») // Официальный сайт Евразийской экономической комиссии http://www. eurasiancommission.org. 11.10.2013. года, за исключением отдельных положений указанных технических регламентов, которые вступают в силу в более поздние сроки.

Разработка технических регламентов в Российской Федерации в настоящее время приостановлена.

Таким образом, нормы международного права в регулировании общественных отношений в сфере технического регулирования оборота продуктов детского питания приобретают первостепенное значение.

В соответствии с п.4 ст.15 Конституции РФ общепризнанные принципы и нормы международного права и международные договоры Российской Федерации являются составной частью ее правовой системы. Если международным договором Российской Федерации установлены иные правила, чем предусмотренные законом, то применяются правила международного договора.

Данная норма позволяет обосновать включение в предмет прокурорского надзора исполнение норм международного права.

К сожалению, в Федеральном законе «0 прокуратуре РФ» предмет надзора, полномочия прокурора по надзору за исполнением норм международного права, специфика данного направления надзорной деятельности прокуратуры не определены, что создает определенные трудности в правоприменительной практике и порождает дискуссии относительно содержания надзора ${ }^{26}$.

При этом приказом Генерального прокурора РФ от 12.03.2009г. № 67 «Об организации международного сотрудничества органов прокуратуры Российской Федерации» на органы прокуратуры возложена обязанность обеспечить неукоснительное соблюдение и исполнение требований международных договоров и соглашений, участниками которых является Российская Федерация, и норм внутреннего законодательства, регулирующего вопросы международного сотрудничества.

Несмотря на недостаточно четкую правовую регламентацию данного вопроса, мы придерживаемся позиции, что в предмет прокурорского надзора входят международно-правовые нормы вне зависимости от форм их имплементации в систему российского права (инкорпорация, легитимация, адаптация, отсылка ${ }^{27}$ ).

\footnotetext{
26 См., например: Шевич Н. Наблюдение, контроль или все же прокурорский надзор за выполнением международных договоров // Законность. 2001, №1. С.12-13; Винокуров А., Чурилов А. Охрана прав и свобод гражданина: обеспечение международных обязательств РФ // Законность.1997. № 6. С. 7-13.

27 См.: Стремоухов А. В. Внутригосударственная имплементация международно-правовой защиты прав че-
} 
Соответственно, в предмет прокурорского надзора за исполнением законов о техническом регулировании в сфере оборота продуктов детского питания входит исполнение вышеназванных международных договоров, заключенных в рамках Таможенного союза и ратифицированных Российской Федерацией.

Вместе с тем в настоящее время не решен вопрос относительно правовой силы технических регламентов, принятых в рамках Таможенного союза по вопросу оборота пищевой продукции в целом и продуктов детского питания в частности, что сохраняет неопределенность и относительно пределов прокурорского надзора в исследуемом нами направлении.

Как Конституция РФ, так и ФЗ «О техническом регулировании», предусматривают возможность установления норм права по вопросам технического регулирования только в международных договорах.

Согласно п.4. ст.4 Закона «0 техническом регулировании» если международным договором Российской Федерации в сфере технического регулирования установлены иные правила, чем те, которые предусмотрены настоящим Федеральным законом, применяются правила международного договора, а в случаях, если из международного договора следует, что для его применения требуется издание внутригосударственного акта, применяются правила международного договора и принятое на его основе законодательство Российской Федерации.

Не углубляясь подробно в исследование вопроса о самоисполняемых и несамоисполняемых международных договорах ${ }^{28}$, отметим лишь, что Пленум Верховного Суда РФ в Постановлении от 31 октября 1995 г. «О некоторых вопросах применения судами Конституции Российской Федерации при осуществлении правосудия» ${ }^{29}$ разъяснил, что суд при рассмотрении дела не вправе применять нормы закона, т.е. российского национального акта, в случаях, когда вступившим в силу для Российской Федерации международным договором, решение об обязательности которого для Российской Федерации было принято в форме федерального закона, установлены иные правила, чем предусмотрено в законе. В указанном

ловека // Международное публичное и частное право. 2013. № 3. С. 17.

28 См.: Международное частное право: учебник - под ред. М. М. Богуславского. М., 2005. С. 51.

29 Постановление Пленума Верховного Суда РФ от 31.10.1995 № 8 «О некоторых вопросах применения судами Конституции Российской Федерации при осуществлении правосудия» // Бюллетень Верховного Суда РФ. 1996. № 1. С. 32-35. случае применению подлежат правила международного договора.

Соответственно, даже для приоритетного применения норм международных договоров, безусловно включаемых в систему российского права, требуется соблюдение порядка их имплементации.

Технические же регламенты, принятые Таможенным союзом, были утверждены Комиссией Таможенного союза (преобразованной впоследствии в Евразийскую экономическую комиссию), соответственно, не являются международными договорами и в силу одного только этого обстоятельства не могут обладать приоритетом применения по отношению к российскому законодательству.

С другой стороны, статьей 1 Соглашения о единых принципах и правилах технического регулирования в Республике Беларусь, Республике Казахстан и Российской Федерации от 18.11.2010 г. прямо закреплено, что технический регламент Таможенного союза утверждается Комиссией Таможенного союза.

Кроме того, п. 2 ст. 2 Соглашения установлено, что технические регламенты Таможенного союза имеют прямое действие на таможенной территории Таможенного союза, что исключает необходимость принятия внутригосударственных актов для вступления технических регламентов в силу.

Ряд авторов полагает, что технические регламенты Таможенного союза обладают особой международно-правовой природой. Несмотря на то, что они не являются международными договорами, в основе их принятия лежит согласование интересов государства, достигнутое путем компромиссов и уступок друг другу. Предусмотренный в рамках Таможенного союза порядок принятия технических регламентов необходим в целях более оперативного введения их в действие ${ }^{30}$.

Данная позиция, на наш взгляд, отражает направленность воли членов Таможенного союза, однако с учетом положений Конституции РФ и Закона «О техническом регулировании»ни в коей мере не позволяет обосновать приоритет технических регламентов Таможенного союза по отношению к законодательству РФ.

В свете укрепления связей в рамках Таможенного союза и активного нормотворчества в рамках данного межгосударственного образования по вопросам технического регулирования следует незамедлительно определиться относительно природы технических регламентов Таможенного союза.

30 См.: Морозов А.Н. Указ. соч. С. 79. 
Органы государственного контроля и суды общей юрисдикции исходят из необходимости их непосредственного применения ${ }^{31}$.

Вместе с тем представляется, что спорные вопросы, касающиеся приоритета данных документов по отношению к национальному законодательству РФ, должны стать предметом рассмотрения Конституционного Суда РФ. Принципиальная и обоснованная позиция по данному вопросу позволит безоговорочно включить в предмет прокурорского надзора за исполнением законов о техническом регулировании в сфере оборота продуктов детского питания и технические регламенты Таможенного союза.

\section{Библиография:}

1. Винокуров А., Чурилов А. Охрана прав и свобод гражданина: обеспечение международных обязательств РФ // Законность. 1997. № 6. С. 7-13.

2. Губарев В. И. Рецепция российским правом соглашений Всемирной торговой организации // Юрист. 2005. № 10. С. 43-48.

3. Кострова Г. И. Фактическое питание и показатели физического развития и нутритивного статуса детей: дисс. ... канд. мед. наук. Архангельск, 2011. 73 с.

4. Марочкин С. Ю. Действие и реализация норм международного права в правовой системе Российской Федерации: М., 2011. 288 с.

5. Международное частное право: учебник / под ред. М. М. Богуславского. М., 2005. 606 c.

6. Морозов А. Н. Международно-правовые аспекты технического регулирования в Таможенном союзе // Журнал российского права. 2012. № 4. С. 77-85.

7. Стремоухов А. В. Внутригосударственная имплементация международно-правовой защиты прав человека // Международное публичное и частное право. 2013. № 3. С. 17-19.

8. Семенов С. В. Качество и безопасность пищевой продукции. Вопросы нормативно-правового регулирования // Торговое право. 2012. № 4. С. 30-40.

9. Шевич Н. Наблюдение, контроль или все же прокурорский надзор за выполнением международных договоров // Законность. 2001. № 1. С. 12-13.

\section{References:}

1. Vinokurov A., Churilov A. Okhrana prav i svobod grazhdanina: obespechenie mezhdunarodnykh obyazatel'stv RF // Zakonnost'. 1997. № 6. S. 7-13.

2. Gubarev V. I. Retseptsiya rossiiskim pravom soglashenii Vsemirnoi torgovoi organizatsii // Yurist. 2005. № 10. S. 43-48.

3. Kostrova G. I. Fakticheskoe pitanie i pokazateli fizicheskogo razvitiya i nutritivnogo statusa detei: diss.... kand. med. nauk. Arkh-k, 2011. 73 s.

4. Marochkin S. Yu. Deistvie i realizatsiya norm mezhdunarodnogo prava v pravovoi sisteme Rossiiskoi Federatsii: M., 2011. $288 \mathrm{~s}$.

5. Mezhdunarodnoe chastnoe pravo: uchebnik/ pod red. M. M. Boguslavskogo. M., 2005. $606 \mathrm{~s}$.

6. Morozov A. N. Mezhdunarodno-pravovye aspekty tekhnicheskogo regulirovaniya v Tamozhennom soyuze // Zhurnal rossiiskogo prava. 2012. № 4. S. 77-85.

7. Stremoukhov A. V. Vnutrigosudarstvennaya implementatsiya mezhdunarodno-pravovoi zashchity prav cheloveka // Mezhdunarodnoe publichnoe i chastnoe pravo. 2013. № 3. S. 17-19.

8. Semenov S. V. Kachestvo i bezopasnost' pishchevoi produktsii. Voprosy normativno-pravovogo regulirovaniya // Torgovoe pravo. 2012. № 4. S. 30-40.

9. Shevich N. Nablyudenie, kontrol' ili vse zhe prokurorskii nadzor za vypolneniem mezhdunarodnykh dogovorov // Zakonnost'. 2001, № 1. S. 12-13.

Материал поступил в редакцию 19 марта 2014 г.

31 См., например: постановление Шестого арбитражного апелляционного суда от 26.02.2014 № 06АП159/2014 по делу № А04-7486/2013, постановление Третьего арбитражного апелляционного суда от 09.01.2014 